\title{
Faith After Sewol
}

\author{
Kyeongil Jung*
}

\section{Abstract}

On April 16, 2014, in the south sea of Korea, a ferry named Sewol sank and 304 people were killed, including 250 high school students who were on their field trip. Koreans witnessed painfully and powerlessly the victims dying in the cold water, which terrified and traumatized them. It was not simply a marine accident but culminating tragic event caused by decades of accumulated social problems and evils. Because of the complexity behind the tragedy, there were mixed responses to the suffering of the victims and their bereaved families, such as empathy, apathy, and antipathy, sometimes sequentially and sometimes simultaneously. The purpose of this essay, therefore, is to examine these complex social and religious responses to the tragedy, focusing on the Christian bereaved families' struggle to make sense of their faith in the face of their unspeakable suffering.

Key-words: Sewol; faith; tragedy; korean theology.

\section{Fé após Sewol}

\section{Resumo}

Em 16 de abril de 2014, no mar do sul da Coréia, uma balsa chamada Sewol afundou e 304 pessoas foram mortas, incluindo 250 estudantes do ensino médio que estavam em viagem de campo. Os coreanos testemunharam impotentes e dolorosamente as vítimas morrendo na água fria, o que os aterrorizava e traumatizava ao mesmo tempo. Não foi simplesmente um acidente marítimo, mas um evento trágico culminante, causado por décadas de problemas sociais e males acumulados. Devido à complexidade por trás da tragédia, houve respostas variadas ao sofrimento das vítimas e de suas famílias enlutadas, como empatia, apatia e antipatia, algumas vezes de forma sequencial e outras vezes simultaneamente. O objetivo deste ensaio, portanto, é examinar essas complexas respostas sociais e religiosas à tragédia, concentrando-se na luta das famílias cristãs enlutadas para dar sentido à sua fé em face ao seu indescritível sofrimento.

Palavras-chave: Sewol; fé; tragédia; teologia coreana.

\footnotetext{
* Saegil Christian Institute for Society and Culture
} 


\section{Fe después de Sewol}

\section{Resumen}

El 16 de abril de 2014, en el mar del sur de Corea, un ferry llamado Sewol se hundió y 304 personas murieron, entre ellos 250 estudiantes de secundaria que estaban en su viaje de estudios. Los coreanos presenciaron dolorosa e impotentemente a las víctimas que murieron en el agua fría, lo que los aterrorizó y traumatizó. No fue simplemente un accidente marítimo, sino un trágico evento como resultado de males y problemas sociales acumulados por décadas. Debido a la complejidad de la tragedia, hubo ante el sufrimiento respuestas mixtas de víctimas y familiares en duelo, tales como la empatía, la apatía y la antipatía, a veces secuencialmente y otras todas a la vez. El propósito de este ensayo, es examinar estas complejas respuestas sociales y religiosas a la tragedia, cuyo centro es la lucha de las familias cristianas desconsoladas, para dar sentido a su fe frente a su sufrimiento indecible.

Palabras claves: Sewol; fe; tragedia; teología coreana

\section{REMEMBER 20140416 ${ }^{1}$}

We remember many events in our life, personal and social, especially if they are important. Yet, as time goes by, the details of events become blurred. That is how our mind works. However, some events are remembered vividly and accurately in detail down through time. The day April 16, 2014 will never be forgotten for myself and many other Koreans as if it was just yesterday or even today. ${ }^{2}$

On April 16, a ferry named Sewol (meaning "Beyond the World") was heading to Jeju Island in the far south of the country. The ferry was carrying 443 passengers and $33 \mathrm{crew}$ members, and the majority of the passengers on board were 325 young students of Danwon High School located in Ansan, a city south of Seoul. Those students were on the field trip to the Island. At 8:52 a.m., a student on the ship called the emergency hotline and informed that the ship was sinking. At 11:18 a.m., the ferry capsized and submerged into the murky and cold sea. 304 people were killed and 250 of them were students from the high school.

It was the saddest spring day I still can and will never forget for the rest of my life. If I might divide my life into two parts, it would be before and after $4 / 16$. The day changed my life and that of many others. Since then

\footnotetext{
1 These words are engraved in yellow bracelet that shows the promise of not forgetting the Sewol Ferry Disaster. Korean people who are solidarity with the bereaved families of the victims wear the yellow ribbons on their bag or yellow bracelet on their wrist.

2 Many of the bereaved families say sorrowfully that they feel like they have been living the same day, April 16, 2014, over and over again.
} 
I have made various solidarity efforts to support the Christian bereaved families. This essay is based on my personal experience of being with and listening to their suffering and faith for the last a couple of years. In this essay, I will closely examine and critically reflect on the following three topics: first, Korean society's mixed responses to the suffering of the victims and their bereaved families, second, the Christian views and attitudes toward the disaster and its victims, and third, the Christian bereaved families' struggle to keep their faith in God in the midst of suffering.

\section{Spring of Empathy}

Life is suffering; suffering is everywhere and every time. In our world, there are various and endless sufferings. Each suffering is special and unique especially to those who directly experience or closely witness it. Therefore, it is hard and undesirable to rank or prioritize certain sufferings over other sufferings. Nevertheless, as Alain Badiou says that an event "compels the subject to invent a new way of being and acting in the situation," (BADIOU, 2001, pp. 41-42) for many Koreans including myself the Sewol Ferry Disaster was a life-changing and challenging event. Why is it so? What makes the tragic disaster so special and unique?

First of all, unlike most other disasters or incidents in the past were usually known to the public after the fact, except those who on the spot, the terrifying spectacle of the sudden overturn and slow sinking of the Sewol ferry was witnessed by most Koreans with their own eyes via media. Every process of the tragedy was broadcasted live in real time from the beginning. Moreover and more painfully, it lasted several days until the capsized ship sank completely into the dark and cold water. No single one came alive out of the sunken ship. Koreans had to witness helplessly and powerlessly people dying in the sea. It was so cruel and tragic that Hye-shin Chung a Korean psychiatrist said that the collective trauma of the 4/16 disaster would be equal to that of the Korean War in 1950.

Second, as mentioned above, the majority of the victims were young teenage students from the same school, who were just 17 or 18 . When the ship was tilting steeply, still there were enough time to get out of the ship and most students were wearing life jackets. However, they did not, could not, try to escape from the sinking ship because they were repeatedly ordered by the crew to stay put in their cabins. The premature and avoidable deaths of 250 
young juveniles from the same school saddened and tortured everyone's heart. (Two of the student victims are still remain unfound as of 2018 summer.)

Third, realizing that the disaster was not accidental but due to deeprooted and long-standing structural problems in Korean society, people were awakened to the harsh reality that they might also have been the victims of the disaster. The President Geun-hye Park and government officials were unbelievably irresponsible and incapable of rescuing people from the disaster. Therefore, Min-kyu Park a novelist poignantly defined the disaster as "an incident that the state did not rescue its people." (PARK, 2014, p. 57) Korean people asked painfully; "Is this really the Sate?"

For these reasons, people felt strong connection with the victims and their families. Indeed, in this time of tragedy, Koreans suffered and wept together as a family. As Min-bock Hahm a Korean poet wrote a poem titled "April, a Sorry Month Even to Breathe," (HAHM, 2014, p. 177). Koreans felt deep guilty whenever they experienced the slightest of joy and laughter. Even some popular comedy shows on TV stopped broadcasting for a couple of weeks and sports games were canceled or postponed. In those early days of shock and grief, literally_not symbolically-all were one. In the face of the sea of suffering, all the differences among people were all nullified. The country itself was a house of mourning and everyone belongs to the family of the deceased. It was a miracle that united all people as one family, a family of co-suffering and empathy. If I may say, it was a spiritual experience of mystical oneness. April 2014 was the cruel month as T. S. Eliot wrote. But at the same time it was a month of empathy.

\section{Cruel Summer, Fall, and Winter: The Second Tragedy}

The time passes and season changes; so is society. The spring of emphatic sorrow and solidarity did not last long. Over time, the social atmosphere changed rapidly and radically. As summer approached, people began to express their compassion fatigue. It seemed that because the disaster was so traumatic that people wanted to rather forget it and return to their everyday life.

In the early stage of the tragedy, Gyeong-geun Yoo, the father of Yeeun Yoo who was a student victim, sadly plead as if he foresaw what was going to happen to the bereaved families: "What we the bereaved families fear the most is to be forgotten. Please promise us that you will continue to remember [us and our children] a month after, one year after, ten years after, 
and forever." (YOO, 2014) We promised. But our memory was too short and our oblivion was too quick. The title of a memorial rally on the 100th day since the tragedy was "Remember Your Tears?" In a sense, it implied the bereaved families' deep fear and anxiety of being forgotten and abandoned by their fellow citizens. We all broke into tears in April of the year but our tears dried up too quickly and the time of empathy seemed to be ended. Thus, Eun-young Jin, a poet and philosopher, wrote an essay titled "Our sympathy is as short as the shadow at noon, and our shame is as long as the shadow of midnight." (PARK, 2014, pp. 67-84) Her lamentation epitomized soberly and sorrowfully the change in society. Before spring ended, apathy spread like a fog through our society.

It did not end there. The worst was yet to come. When the summer came, the most drastic and dreadful change took place. Apathy developed into antipathy. At first, there were malicious rumors around the internet and conservative media, claiming that the bereaved families received a colossal amount of compensation money and asked to be given various privileges, which were not true at all. Some hate groups insulted the Sewol families by describing them as greedy parents who desired to draw profit from the deaths of their children. In addition, a series of hate-filled mockeries-for example, "corpse merchants" and "tax thieves" — were made against the victims and their families, which was cruel and inhumane violence.

This change was ignited and led by the government administration and ruling party. It soon turned out that the government itself was responsible in many aspects for the disaster. In terms of the structural causes of the disaster, it is widely known that the neoliberalist government deregulated the safety standard of the ship maintenance and operation. As a result, when the Sewol ferry was imported from Japan in 2012, it was already 18 years old. The company would not have bought the ship if the Korean government had not established a deregulation policy that extended the ferry's service periods from 20 to 30 years. In addition, the ferry company renovated the ship, overextending its structure, which is suspected as a cause of the sinking of the ferry. And also, it is revealed that the ferry was usually overloaded with cargo, such as iron bars for construction. Another problem that shocked many was that, of the 32 crew members 19 were irregular, part-time workers, including the captain and chief mate. People were shocked and angry, knowing that the crew abandoned and escaped from the sinking ship while the passengers were still inside following their order. To be sure, it would be 
unfair to say that the disaster took place because they were part-time workers. The point however is that the shipping company's primary concern was not safety but profit. It hired part-time crew members without job security and sufficient safety training in order to cut labor cost. Still the causes of the disaster are mostly unknown. Yet, those factors abovementioned show that one of the causes of the tragic disaster was neoliberal greed that prioritizes corporate profit over human life.

A more serious problem was the government's unbelievable inability to rescue people. The government had no actual working disaster central tower and system, which had been established by a previous progressive government but abandoned by the following two conservative governments. Ki-choon Kim, the Blue House Chief of Staff for Korea President, said later at an investigative hearing that the Blue House is not a national crisis control tower. Without knowing what and how to do, the Maritime Police did not take any practical and effective action to rescue the passengers. Most of the survivors were rescued by themselves or local fishers nearby. Furthermore, the president herself was absent for "seven hours" on April 16, while the ferry disaster was going on. All this problems and issues fueled peoples' suspicion that the government itself was directly and indirectly responsible for escalating a marine accident into tragic disaster. That would be the main reason why the government obstructed or sabotaged the investigation process. In fact, the government, ruling party, conservative media, and rightwing groups conspired together to hide the truth. The worse was that they politicized the tragedy in order to divide people. For example, the presidential spokesperson even used a term "genuine bereaved families" as if there were ungenuine bereaved families.

The mainstream media was also a part of social disaster. In the morning of the disaster, every news media reported in unison that everyone in the ship was rescued. Missing critical spirit, they just delivered the news based on the government's announcements. There were no question, no doubt, and no analysis. Besides, the news press did not have compassionate spirit, too. The contents and ways of breaking news in the press were filled with sensationalism. It seemed that the media workers and executives did not know how to talk about and treat those who suffer. For instance, the chief editor of the newsroom of KBS, the national broadcaster of Korea, made an imprudent and improper comment that the number of the casualty of the Sewol ferry incident was relatively small compared with the annual 
casualty of car accidents in Korea. It was a fact but not the truth of the Sewol tragedy. In their deep anger, on May 8th, 2014, the families and parents of the victims went to KBS, holding the portrait photos of their children in their arms and bosoms, to protest against the distorted and malicious news reports. And, realizing the strong connection between the government and media, the 4/16 bereaved families left KBS and headed to the Blue House, the Korean presidential residence. Expectedly, the police blocked their way and the bereaved families and parents staged their first overnight sit-in protest on the street. Sadly and ironically, that day May 8th was the Parents' Day in Korea. Since then, the Sewol families started their long and determined struggle against the government demanding to reveal the truth of the disaster.

However, the stronger the bereaved families' struggles became, the stronger antipathy against them was developed. In the summer and fall of the year, the hate-filled antipathy against the bereaved families led to corresponding hateful actions. The most cruel and terrible hate action was "food binges" committed by right-wing groups in front of the Sewol families who were on hunger strikes at the Gwanghwa-mun Square in central Seoul. They mocked and insulted parents who lost their children. It was an unthinkable hate crime. Having witnessed all this, I had to ask: What on earth did the bereaved families have to face such hatred and violence, not comfort and support? What the Sewol families wanted was simple and clear: to know why their children had to die. Was this asking too much? Why did we Koreans forget so quickly our own tears and promises in last spring?

In a deeper sense, we Koreans did not forget. Rather, we remembered our tears and promises, and realized the meaning of them. It meant that we had to stop living with the neoliberal way of life that caused the Sewol ferry disaster. It was like getting off from a sinking ship in order to live. For us, to stay in the ship of neoliberalism was painful, but to get out of it was more fearful. Our fear exceeded our pain. Moreover, to resist against neoliberalism was to resist against ourselves because we complied with the status quo. There was no fundamental difference between the left and right, between the progressive and conservative, between the haves and have-nots, and between the religious and non-religious in terms of following neoliberal worldviews and principles, that is, individualism and competition. Having internalized this neoliberal way of life, we have lost the sense of community and cooperation. Therefore, we wanted to forget our tears and to return to the way we had lived before Sewol. Nevertheless, the pain and memory of the 
tragedy was so vivid, obvious, and intense to all of us that it was almost impossible to forget it. Furthermore, the unflagging and living presence of the bereaved families per se was a constant reminder of where we should go and how we should live after Sewol. Thus, we tried to become apathetic and even antipathetic to the Sewol families. In short, the sinking of MV Sewol revealed our collective complicity with neoliberal greed. That is why Gyeong-dong Song, a protest poet, said that "All society was MV Sewol; our life today is Sewol." (SONG, 2014, p. 89)

To be sure, since the 4/16 disaster was so tremendous that neoliberal greed alone was not enough to provoke and justify the antipathy against the bereaved families. Another cause of such antipathy was ideological hatred. As summer of the year approached, far-right hate groups began to condemn and call the victims' families as jongbuk, which means "pro-North Korea followers." It was simply a nonsense because almost all the families of the victims had not involved in political activism, especially that of the left. Yet, conservatives and right wing groups had a stubborn logic and viewpoint that any movement that threatened the status quo was jongbuk because it could potentially and consequently benefit North Korea. This ideological belief was irrational and prejudicial but it was powerful enough to poison people's mind.

This ideological hatred is the result of the tragic history of Korea. In 1945, right after Japanese occupation was over, the Korean Peninsula was divided by the world powers into two, North and South Koreas. Then, in 1950, the Korean War broke out, which was the first international ideological war between communist and capitalist nations. Therefore, ideological hatred was extreme and violent. What was worse was that not only soldiers but also civilians took part in killing their families, friends, and neighbors in the name of ideology. Thus, Chan-seung Park a historian calls the Korean War "the war that went to village." The Korean War was cease-fired in 1953, but ideological hatred did not. The poison of ideological hatred in the form of anti-communism has continued to divide and dominate the Korean society throughout its contemporary history. Since the power of this ideological hatred is so strong and effective that right-wing governments in Korea have used it as an almighty tool to oppress and destroy people's protests. For this reason, it was not really surprising that the right-wing government and groups politicized and stigmatized the Sewol families and their supporters as jongbuk.

Nevertheless, and gratefully, the society was not monolithic. Even though the Korean society in general seemed to become apathetic and 
antipathetic to the 4/16 families, isolating and insulting them, there were also a great number of people who showed their deep compassion for and strong solidarity with the suffering families of the victims. The more the 4/16 families were accused and attacked by the government and right wing groups, the more empathic and compassionate people gathered together to support and be with the bereaved families. Indeed, many citizens have determinedly participated in the struggle to reveal the truth about the disaster. They were called "Sewol activists," most of whom were ordinary people whose life after Sewol was fundamentally changed. They together with the bereaved families created a community — or better a family_of suffering and hope.

Finally, after nationwide struggles for months, when winter was coming, the Korean parliament passed a bill to set up a special investigation commission on the Sewol ferry disaster. Yet, the situation was not promising. The government continued, more aggressively, to sabotage the implementation of the bill and necessary actions. On November 11, the government called off the search for the unfound victims from the sunken ferry. Nine victims had to go through winter in the cold water of the sea. The antipathy and hatred towards the bereaved families were still lingering in the air. Nothing revealed, nothing changed. The bereaved families were deeply hurt. To them, apathetic and antipathetic Korean society was colder than winter. It was the second tragedy of the Sewol families after they lost their beloved ones.

\section{Church That Hurt: Complexity and Complicity}

It was frustrating to witness that some of the Christian churches showed and shared the same apathy and antipathy toward the 4/16 families. It was because the church, too, was not immune to neoliberal greed and ideological hatred. Yet, the Christian responses to the disaster was more complex than in society because Christians had peculiar religious symbols and languages with which they might comfort or confuse the suffering people.

Embarrassingly, when the Sewol ferry sank and people were dying in the sea, it was Passion Week for Christians, a time to remember and meditate on the suffering of the crucified Jesus. In a sense, during the Passion Week, Christians could identify the tragic event of the ferry sinking with the crucifixion event of Jesus because the sunken Sewol ferry was a cross lying in the water. However, that year's Easter Sunday made no sense for Christians. On Easter morning, Christians are supposed to celebrate the good news of the resurrection of Jesus. But, on Easter 2014, the good news was shadowed 
by the bad news that the victims were still inside the capsized ship. Passion Week did not end; the suffering of Jesus and his beloved people continued after Easter.

What was more embarrassing was that some church leaders hurt the Sewol families with their theological language. For instance, a megachurch pastor said: "There must be some reasons why God allowed the ferry to sink. It was because the country was sinking. God couldn't let Korea be like this. Thus, God gave the people an opportunity [not to sink] by sinking those young beautiful students." It was a typical traditional theodicy. In fact, many Korean Christians thought and believed that there must be a good reason why the omnipotent and omniscient God allowed the Sewol ferry disaster. It might be theologically thinkable but to speak it without considering how it would affect the suffering people was unthinkable and unacceptable. Like Job's friends, they spoke too much in the face of the suffering of the bereaved families and their theological words were apathetic. In the midst of the unspeakable tragedy a more humane and religious language would be rather apophatic, not apathetic.

There were also socially and ideologically problematic utterances by conservative Christians. For instance, just four days after the disaster, another fundamentalist pastor made a discriminatory statement as follow: "The students from poor family should have gone to their field trip to the cheap place like Bulkook-temple at Kyeong-ju, [which is a historic city in Korea], not the high-cost Jeju Island." This statement revealed that the church justified economic disparity between the rich and poor as a fait accompli. In fact, conservative Christians' main concern was money, not life. On the same day, the Christian Council of Korea, which is the most conservative Christian organization in the country, had an executive meeting and its main agenda was to plan a visit to a local market in Ansan to promote consumption, not to comfort the families of the teenage victims.

Some Christians went too far by politicizing the bereaved families and people's efforts to reveal the truth of the disaster. To take an example, a farright pastor said right after the tragedy that "The jongbuk ("pro-North Korea followers") and left are madly joyous, organizing memorial events. Why? They got a great source to use [for their political purpose]." They did not stop there. On June 1st, 2014, just three days before the Local Election Day nationwide, some of the conservative church leaders invited the president Park to a special prayer meeting. It was a kind of religious and political 
exoneration for the government and ruling party because, at that time, the president and her administration were severely criticized by the public for their total failure to save people. The ruling party won the election. All this show that the Korean church is not fundamentally different from society. It was inevitable because Korean church have also been infected and baptized by the mammonic greed and hatred.

The worst and saddest thing was that not only some church leaders but also many lay Christians showed their apathy and antipathy against the bereaved families. It is said that Christians spread the insulting rumors and fake news about the parents of victims via their instant messaging network and SNS. Christian bereaved families experienced this more closely and directly. Many of them painfully spoke that they were hurt by their pastors and church members who told them they had to let go of their children because they are now in God's arms in heaven. Eun-hee Park, the mother of Ye-eun Yoo, said that the most hurtful word she heard from Christians was "God's will." And also, at her daughter's funeral, she was told by her fellow Christians not to cry because her child went to a good place, which is heaven. (LEE, 2016) Soon-hwa Choi, the mother of Chang-hyun Lee, was a devoted Christian and wanted to stay in the church but had to leave because of her church members' cold attitudes toward her. She was a Sunday school teacher in her church and continued to teach children even after the disaster. One day, however, she heard that her church members wanted her to stop teaching children because she shaved her head to protest. Out of feeling betrayed and abandoned by her brothers and sisters in faith, she left her church. For a similar reason, many Christian bereaved families left their home churches. The church for the bereaved families was not a safe and comforting place to stay and live. The church hurt, not healed.

\section{A Church of the Brokenhearted and a Liberation Theology of Suffering}

Many of the Christian bereaved families left their home churches; but, they did not leave God. In its deepest sense, they left their churches in order to continue to believe in their God. They could never understand and believe in such God who allowed the tragedy. They had to believe in God to question and protest to God.

In 2015 spring, the Christian bereaved families created a meeting place at the parking lot of the Sewol Memorial in Ansan and began their own 
bible study, prayer meeting, and worship service. Since then, every Sunday afternoon, they held worship service. The participants to the worship service were the Christian bereaved families and visiting Christians who came to express their sorrow and solidarity with their suffering brothers and sisters. Usually, visitors led the worship service and the bereaved families shared their testimonies about their suffering and struggle. After the worship service was over, all the participants were invited to a simple but heartwarming meal table like communion. It was a church of the brokenhearted.

I together with my church members have regularly attended the service once a month from the early fall of 2015. Having participated in the worship service of the 4/16 Christian families, I came to learn and realize how the Christian Church began after the crucifixion and resurrection of Jesus of Nazareth. As early Christians gathered together to keep and share their memory of Jesus and hope for salvation, the 4/16 families-by blood or by the heart-also continued to meet together in order to remember their beloved ones and to transform society into a safer and better place to live. It was a community of the memory of suffering and hope for salvation.

However, it must be noted here that this place for Bible study, prayer, and worship service was never a comfortable haven for the Christian bereaved families. Rather, it was a spiritual and social furnace in which the bereaved families' love, pain, doubt, struggle, and hope were melted and cast into a liberation theology of suffering. It was, again, never a comfortable and comforting process. The parents and families of the victims protested, struggled, and wrestled with God. They are indeed today's Israel- "one who struggles with God."

It has been surprising, touching, and sometimes fearful for me to listen to the theological struggles and insights of the Christian bereaved families. They were Job's protests, the Psalmist's lamentations, and the Prophet's proclamations. Thus have I heard:

I hope our society will remember our brothers and sisters not as poor children who died on their way to a field trip but as those who changed the world. - Bona Park, the sibling of Seong-ho Park.

I left my church but could not leave God. I have been strengthened by people. They are gods sent by God. ...... Through them, 1 realized God exists. Soon-hwa Choi, Chang-hyun Lee's mother. 
The church should be where suffering parents, who are the most suffering people, are, isn't it? - Jong-taek Moon, Jisung Moon's father.

Where is your God? The God I believe is inside the ship embracing the nine people. - Eun-mee Park, Da-yoon Huh's mother.

Eun-hee Park, Ye-eun Yoo's mother, who is the core organizer of the worship service at Ansan once told me that "We don't really know how we could speak such surprising words. We feel these words are not from us." She is right, I believe. They are God's words through them to us. The more I listened to God speaking through the bereaved families, the less I could speak theologically. In fact, there are unspeakable sufferings that our theological language cannot properly speak about. No words can comfort and make sense to those who are in ongoing pain and suffering. In the face of the suffering of others, the most proper and possible language we may speak would be silence and solidarity. To be sure, at some point, theologians may learn how to speak right. But, as W.F. Hegel said that the owl of Minerva flies at the dusk, there is a time to speak and a time to be silent empathically and act compassionately. Having realized and learned this, I became silent to listen to and be with the bereaved families.

After the tragedy, most of the Christian bereaved families had difficulties of making theological sense of their suffering. As said above, many Christian pastors and laity believed that there must be a certain divine purpose and providence behind the tragedy because their God is omnipotent and omniscient, which accord with the traditional theodicy. Such God might be all-powerful and all-knowing, but not all-loving. Theodicy tortured the Christian bereaved families. Even, at times, some Christians who attended the Sunday worship service at Ansan hurt and upset the bereaved families with their traditional theodicean views and words. It hurt the 4/16 family so deeply that there sometimes were conflicts between the Christian bereaved families and visitors. At first, I thought it was an expression of their pain. Yet, soon, I realized that they were struggling not to lose their faith in God. They did not want to make their God a mass-murderer.

When the tragedy occurred, Eun-hee Park was an assistant pastor at a local church where her daughter Ye-eun had cherished and cultivated her faith, friendship, and dream. The Bible was always central in her and her daughter's their faith and life. Yet, after the Sewol disaster, park could not read the Bible. One day, at Ye-eun's funeral, Park opened her daughter's 
bookmarked bible and threw it away because it told a story of Christian martyrdom. It hurt and confused her. She could never believe and accept that her daughter was to be a martyr. Yet, she had to return to the bible again and again because she wanted to know the $W$ hy. After reading the bible again and again, suddenly, she got a message from God that "Ye-eun is not called to be a martyr, you are!" Since then, she committed herself to reveal and tell the truth with a martyr's heart. (PARK, 2017) As times went by, the more she along with the bereaved families read the bible, the more the biblical stories become real and vivid to her. It was her story and their story. At a Minjung theologians' meeting, Park mentioned first the text-context debate $^{3}$ in Minjung theology and said: "As I read the Bible again [after the tragedy], I was jolted to realize that the events in the Bible were the context. They were no longer simply the text. Our life to endure was the text. In fact, I couldn't distinguish them." " It was possible because the bereaved families read the abundant biblical stories of suffering in the light of their living experience of sorrow and suffering after Sewol. It is their way of reading the Bible and their life.

The theological evolution of the bereaved families was so radical as to accept even the possibility of universal salvation. In another Sunday, a visiting Christian woman shared her reflection on the visit to the Memorial just before the worship service began. She said to the bereaved families that, looking at the portraits of the victims, she felt sorry for non-Christians because they would not be in heaven. She was certainly a warm-hearted Christian who came to Ansan to show her solidarity with the bereaved families. Yet, her Christian belief faith was too traditional to be accepted by the Christian bereaved families to whom old and traditional beliefs collapsed. The bereaved families were upset and hurt again but this time they managed to restrain their anger. It was possible because the bereaved families experienced this kind of situation many times. Anyway, next Sunday, recalling the previous Sunday's happening, Soon-hwa Choi said sadly but faithfully: "I don't and can't believe that many of my son's friends are not in heaven because they were not Christians. This might sound heretical but that's what I believe

\footnotetext{
3 Minjung theologian Nam-dong Suh argued that the Bible is the context and we in minjung reality are the text, while Byung-mu Ahn argued that we cannot distinguish the text and context.

4 "Meeting Jesus Again Through The Sewol Disaster: The Testimony of Ye-eun Yoo's Mother," Kookmin-Ilbo(The Kukmin Daily), July 12, 2016. http://news.kmib.co.kr/article/ view.asp?arcid $=0010775545$.
} 
now." I responded to her: "If you are a heretic because you believe so, you are not alone. I'm with you."

The Christian bereaved families' faith is in concordance with the Liberation Theology in their common emphasis on praxis. In liberation theology, praxis is the "first act" and theology "second act". Latin American liberation theologians are right that what is important in liberation theology is liberation, not theology. Likewise, the core of the bereaved families' liberation theology is the liberation of the victimized, marginalized, and oppressed, including themselves. They are not interested in theological speculation but are eager to work for the liberation of the sufferers. What has touched my heart the most since I met with the Christian bereaved families is their passionate and compassionate solidarity with other suffering people. It is conservative to say that the 4/16 families are the sufferers among the sufferers at least in Korea. Therefore - not nevertheless - no suffering is foreign to them. Out of the depths of their own suffering, they know and feel the suffering of others as their own. Thus, they have visited the victims of lay-off, gentrification, police brutality, discrimination, and so on. For instance, at the public funeral of Nam-ki Baek, a 69 years old farmer and social activist who was the victim of police violence, Gyeong-geun Yoo introduced and identified himself as "the son of Nam-ki Baek and father of Ye-eun." The victims of the structural and physical violence become a social family.

One night in the late fall of 2016, Dalit theologians from India and Minjung theologians of Korea had a joint worship service at the sit-in site at the Gwanghwa-mun Square. Soon-hwa Choi participated in the worship and delivered a talk. She said that "Like 'Rachel weeping for her children and refusing to be comforted, because they are no more,' I, too. refuse to be consoled till the truth is revealed." Those Dalit theologians had never met Choi before. Yet, they understood and felt her deep pain, and she did the same to them. Dalit theologians gave her heartwarming hugs as if she was their family member. The Sanskrit word dalit means "broken." The brokenhearted know the brokenhearted. They open their hearts to one another. They have what Parker Palmer calls the "heart broken-open."

\section{Mothers and Fathers: The Subject of History}

In the winter from 2016 to 2017, Korea's Candlelight Revolution took place that brought tens of millions people to the streets, demanding the impeachment of the President Geun-hye Park. It was nationwide struggle 
organized by the civilians themselves. The central place for the revolution was Gwanghwa-mun Square in central Seoul, where the 4/16 families and citizens have stayed in tents and staged long and hard protests against the government for more than three years. One of the core demands of the revolution was to investigate the " 7 hours of President Park's absence" on April 16, 2014. Finally, after peaceful but persistent demonstrations, people ousted President Park from her office and, at the end, on March 10th, 2017, Korea's Constitutional Court upheld former President Park's impeachment. Many admit that the Candlelight Revolution would have not been possible if the Sewol families had not continued their struggle against the government that hid the truth of the Sewol tragedy.

That Friday spring morning, when the constitutional decision was made, Soon-hwa Choi and a couple of her friends, including myself, were picketing in front of the Blue House, which was our weekly demonstration. Then, around noon, we saw tens of thousands of marchers with colorful flags and banners heading to the Blue House, cheering the victory of democracy. Upon encountering us, they thanked us, the 4/16 families, for our persistent and unflagging struggle to change our society. Indeed, it was a victory of citizens and of the $4 / 16$ bereaved families.

At this point, it must be noted that the number of the bereaved families are at most several hundred people and not all of them have participated passionately and continuously in the long and difficult struggle thus far. As such, some have fought, and some have been frustrated. They are not a big group in terms of their numbers. Yet, at one protest in April in 2015, when the social support and struggle were weakened and declined, the Sewol families rigorously proclaimed that "We will become the subject of history!" They have proved they are, indeed. But, they were not heroic or veteran democracy fighters. Before Sewol, they were just ordinary mothers and fathers of their beloved children. Yet, their love for their deceased children before and after Sewol made them extraordinary. No matter what the circumstances have been, they have never stopped their committed and determined efforts to reveal the truth of the tragedy because they are mothers and fathers of their beloved children. They, ordinary parents with extraordinary hearts, sing a song titled "We Promise."

We are your mothers

We are your fathers

We are your parents

Who buried you in our hearts 
You are our sons
You are our daughters
You are all our sons and daughters
Who are encrypted in our hearts.
Who are hiding the truth of the day?
Who are interrupting the cry of anger?
We would never keep silence
We all act
If we keep silence
There will be no future at all
We will reveal all the truth
We will punish all the criminals
We will change the world
We promise, we promise. (YOON, 2014)

They have kept the promise through their actions because they are parents of their children. They are mothers and fathers, the subject of history, who have changed and will continue to change our society.

In April 2018, right after the fourth anniversary of Sewol Ferry Disaster was solemnly held at Ansan, the Sewol Memorial was deconstructed. However, the bereaved families' struggles do not end. The whole truth of the disaster is still not revealed and a safer, more just, and more compassionate society they hope is yet to come. A long and hard journey to truth and justice is ahead of the bereaved families. On May 12, 2018, the Sewol families and citizens established the 4/16 Foundation through which we commemorate the victims of the tragedy and contribute to social change of Korea and beyond. One of our current efforts is to build a 4/16 Life and Safety Park in Ansan in which people from many corners of society will learn about the tragic but transforming history of the Sewol Ferry Disaster and dream of a world that prioritizes life and safety over profit.

\section{Epilogue: A Church of Suffering and Hope in the Wilderness}

When the Sewol Memorial was deconstructed this spring, the Christian worship place at the parking lot of the Memorial was also removed. Although the small and simple container box place for prayer and worship service was gone, the Christian bereaved families and their friends did not disperse. Since May this year, they have had a monthly worship service at an open field nearby the reserved area for the 4/16 Life and Safety Park. There are 
still the resistance of local people to the construction of the park because of their worries about economic downside. Sadly, prejudice and selfishness lingers in the air. Therefore, our worship is still both our prayer and our protest. We pray and protest for the change of the human heart and society.

Nowadays, one of the big social issues in Korea is a megachurch's hereditary succession. Simply put, it happens because the church is too big and rich. Compared to the megachurch, the 4/16 Christian families' church is literally no-thing. Our worship place in the field has no ceiling and walls to protect us from sunlight, wind, and rain and snow. The last summer of Korea was abnormally hot. Nevertheless, or therefore, many Christians from various communities participated in the worship service in the field. Under the scorching sun and in the sweltering heat, we together as one body of Christ prayed, sang, and spoke about hope for another and better world. Without building, without institution, and without doctrines, the Christian bereaved families experience the genuine and true church of Christ. In the wilderness of suffering and hope, the brokenhearted meet Jesus the "priest of han ("broken heart" in Korean)." That is where Jesus is and where his church is.

\section{Bibliographical References}

BADIOU, Alain. Ethics: An Essay on the Understanding of Evil, New York: Verso, 2001.

EUN, Goh et al. We Are All MV Sewol, Seoul: Silcheon-Munhak-sa, 2014.

HAHM, Min-bock, "April, a Sorry Month Even to Breathe," in: EUN, Goh et al. We Are All MV Sewol, Seoul: Silcheon-Munhak-sa, 2014.

KIM, Ye-ran et al. The Country of the Blind, Seoul: Munhak-Dongne, 2014.

LEE, Eun-hye, "Pastors Breaking into Tears Listening to the Sewol Families' Profession of Faith," Newsnjoy, March 8, 2016. http://www.newsnjoy.or.kr/news/articleView. html?idxno=202309

PARK, Eun-hee, Dangdang News, May 6, 2017. http://www.dangdangnews.com/news/ articleView.html?idxno $=28242$

PARK, Min-kyu, "The Country of the Blind," in: KIM, Ye-ran et al. The Country of the Blind, Seoul: Munhak-Dongne, 2014.

SONG, Gyeong-dong, "We Are All MV Sewol," in: EUN, Goh et al. We Are All MV Sewol, Seoul: Silcheon-Munhak-sa, 2014.

YOO, Gyeong-geun, "What we fear the most is to be forgotten," Catholic News, May 22, 2014. http://www.catholicnews.co.kr/news/articleView.html?idxno=12520

YOON, Min-seok, "We Promise" in: EUN, Goh et al. We Are All MV Sewol, Seoul: SilcheonMunhak-sa, 2014. 